\title{
Faktor yang Berhubungan dengan Kejadian Sakit Perut Berulang pada Anak Usia 7-12 Tahun di Kecamatan Padang Timur
}

\author{
Amelia Yendra, Yusri Dianne Jurnalis, Nice Rachmawati Masnadi \\ Bagian Ilmu Kesehatan Anak Fakultas Kedokteran Universitas Andalas/RSUP dr. M. Djamil, Padang
}

Latar belakang. Sakit perut berulang merupakan suatu keluhan yang sering datang pada praktik dokter anak usia sekolah. Seringkali penyebab tidak terdeteksi dan diyakini sebagai keluhan fungsional.

Tujuan. Mengetahui prevalensi dan hubungan faktor risiko dengan kejadian sakit perut berulang pada anak usia 7-12 tahun di Kecamatan Padang Timur.

Metode. Studi potong lintang dilakukan pada Januari - April 2019 terhadap 153 anak berusia 7-12 tahun di tiga Sekolah Dasar Kecamatan Padang Timur, Kota Padang. Data dikumpulkan dari pengisian kuesioner sesuai Kriteria Roma III yang diisi oleh orang tua siswa yang sebelumnya sudah menandatangani lembaran persetujuan orang tua.

Hasil. Nyeri perut berulang dialami 6,5\% dari 153 anak. Hasil uji chi-square terdapat hubungan bermakna antara paparan kejadian yang dapat menyebabkan stres dari rumah, sekolah, dan tingkat pendidikan orang tua dengan kejadian sakit perut berulang pada anak usia 7-12 tahun dengan kejadian sakit perut berulang. Hasil analisis regresi logistik didapatkan paparan kejadian dalam hidup yang dapat menyebabkan stres dari rumah merupakan faktor risiko kejadian pada anak usia 7-12 tahun di Kecamatan Padang Timur. Kesimpulan. Paparan kejadian dalam hidup yang dapat menyebabkan stres dari rumah merupakan faktor risiko kejadian sakit perut berulang pada anak usia 7-12 tahun di Kecamatan Padang Timur. Sari Pediatri 2020;22(4):203-7

Kata kunci: sakit perut berulang, prevalensi, faktor risiko

\section{Factors Affecting Recurrent Abdominal Pain in Children Aged 7-12 Years Old in The East Padang District}

Amelia Yendra, Yusri Dianne Jurnalis, Nice Rachmawati Masnadi

Background. Recurrent abdominal pain (RAP) is a frequent complaint in general practice in childhood. Very often the etiology is undactable an are considered functional.

Objective. This study aimed to determine the prevalance and association between risk factors and the incidence of RAP in children aged 7-12 years old in the East Padang.

Methods. This cross-sectional study was performed in January-April 2019 on 153 children aged 7-12 years old in three elementary schools in East Padang District. Data were obtained using the Rome III questionnaire filled in by of the students who had previously been approved by the parents.

Result. Recurrent abdominal pain was experienced by $6,5 \%$ of 153 children. Chi-square test showed a significant correlation between the exposure to stressful life event from the house life, exposure to stressful life event from the school, and also those whose parents had lower educational attainment with the incidence of recurrent abdominal pain. Multivariate analysis show that the risk factor of recurrent abdominal pain is exposure to the stressful life event in the house life.

Conclusion. Prevalence recurrent abdominal pain in 6,5\% and stressful life event in the house life is the risk factor of recurrent abdominal pain in children aged seven until twelve years old. Sari Pediatri 2020;22(4):203-7

Keywords: recurrent abdominal pain, prevalence, risk factor

Alamat korespondensi: Yusri Dianne Jurnalis. Departemen Ilmu Kesehatan Anak FK UNAND/RSUP dr.M.Djamil Jl. Perintis Kemerdekaan. Padang, Sumatera Barat. Email: yusridianne12@gmail.com 
S akit perut merupakan salah satu keluhan yang sering ditemukan pada praktik dokter sehari-hari terutama pada anak. ${ }^{1}$ Dari seluruh total kunjungan pada dokter spesialis anak 2-4\% diantaranya datang dengan keluhan sakit perut berulang. ${ }^{2}$ Keluhan sakit perut yang cukup berat pada anak menjadi salah satu penyebab ketidak hadiran di sekolah, penurunan konsentrasi belajar, dan menyebabkan ketidakmampuan anak dalam mengikuti kegiatan olahraga dan kegiatan ekstrakulikuler lainnya. ${ }^{3}$ Kondisi yang tidak kunjung membaik dan mengganggu menimbulkan ketidakpastian diagnosis, kronisitas, dan tingginya kecemasan orang tua. Hal inilah yang menyebabkan manajemen dari dokter umum maupun spesialis anak menjadi sangat sulit, menghabiskan banyak waktu, dan mahal. ${ }^{1}$

Istilah sakit perut berulang atau recurrent abdominal pain (RAP) pertama kali diperkenalkan oleh Apley dan Nais pada akhir tahun 1950. ${ }^{4}$ Adapun yang dimaksud dengan sakit perut berulang pada anak adalah serangan sakit perut berulang yang terjadi sekurang-kurangnya tiga kali dalam jangka waktu tiga bulan terakhir yang dapat mengakibatkan terganggunya aktivitas seharihari. Keluhan ini dilaporkan terjadi pada $10-12 \%$ anak usia sekolah di negara maju. Studi epidemiologi di Asia juga melaporkan prevalensi yang sama. Sakit perut berulang umumnya banyak terjadi pada anak dengan rentang usia 4 sampai 14 tahun. ${ }^{1}$ Orang tua pada umumnya tidak banyak mengetahui tentang keluhan ini dan menganggap keluhan tersebut dapat pulih dengan sendirinya dan bersifat sementara. ${ }^{5}$

Penyebab sakit perut berulang dikelompokkan menjadi dua, yaitu disebabkan oleh suatu kelainan organik dan non-organik (fungsional). Dilaporkan 9-5\% keluhan sakit perut berulang disebabkan oleh adanya suatu kelainan organik. Kelainan organik tersebut dapat berupa infeksi, inflamasi, obstruksi, sindrom malabsorbsi, kelainan ginekologi, gangguan saraf, dan lainnya seperti keracunan makanan. ${ }^{6}$ Apabila saat pemeriksaan tidak ditemukan gejala dan tanda adanya suatu kelainan organik, maka keluhan sakit perut berulang tersebut dapat dikelompokkan sebagai gangguan non organik atau fungsional yang umumnya dipengaruhi oleh faktor biopsikososial. Faktor biopsikososial tersebut, antara lain, perilaku, emosional, lingkungan, psikologi, dan faktor lainnya diluar ketidak normalan saluran cerna. ${ }^{7}$ Selain itu, berdasarkan hasil penelitian yang dilakukan di Amerika dan Eropa dilaporkan bahwa faktor psikologis, status sosioekonomi rendah, adanya keluhan gangguan cerna pada orang tua, dan orang tua tunggal dihubungkan dengan kejadian sakit perut kronis. ${ }^{8}$

Data mengenai prevalensi dan faktor risiko sakit perut berulang pada anak hingga saat ini tidak banyak dilaporkan terutama di Kota Padang. Berdasarkan data dari seluruh Puskesmas di Kota Padang pada tahun 2017 ditemukan angka kunjungan akibat sakit perut terbanyak berada di Kecamatan Padang Timur. ${ }^{9}$

\section{Metode}

Penelitian dilaksanakan pada siswa/i sekolah dasar di Kecamatan Padang Timur. Jenis penelitian ini adalah analitik dengan rancangan cross sectional. Variabel independennya adalah sakit perut berulang dan variabel dependennya adalah jenis kelamin, paparan kejadian dalam hidup yang menyebabkan stres dari rumah, paparan kejadian dalam hidup yang dapat menyebabkan stres dari sekolah, tingkat pendidikan orang tua, tingkat pendapatan orang tua, riwayat keluhan sakit perut berulang pada keluarga kandung. Penelitian dilakukan dari bulan Januari sampai April 2019.

Populasi adalah siswa/i sekolah dasar di Kecamatan Padang Timur Kota Padang. Pemilihan SD di daerah Kecamatan Padang Timur dilakukan dengan teknik sampling acak sederhana. Sampel penelitian 153 siswa/i sekolah dasar yang memenuhi kriteria inklusi dan eksklusi. Kriteria inklusi yaitu siswa/i sekolah dasar yang terdaftar pada tahun ajar 2018/2019 di Kecamatan Padang Timur usia 7-12 tahun, mendapat izin oleh wali untuk mengikuti penelitian, siswi tanpa masalah menstruasi, wali bersedia diwawancara, siswa/i yang tidak memiliki sakit perut berulang dengan kelainan organik. Kriteria eksklusi yaitu siswa/i yang tidak hadir pada saat penelitian.

Pengumpulan data dengan menggunakan kuesioner Kriteria Roma III yang telah diterjemahkan pada penelitian terdahulu. ${ }^{10}$ Siswa yang memenuhi kriteria inklusi terlebih dahulu diberikan surat pernyataan persetujuan mengikuti penelitian oleh orang tua sebelum mengisi kuesioner Roma III. Selanjutnya kuesioner diisi oleh orang tua murid dan pada anak dengan keluhan sakit perut berulang, akan dilakukan wawancara langsung terhadap anak serta orang tua/wali.

Data dianalisis secara statistik berdasarkan variabel yang dinilai menggunakan sistem komputerisasi yaitu 
analisisi bivariat dan multivariat. Analisis bivariat menggunakan uji chi-square dan dikatan bermakna apabila nilai $\mathrm{p}<0,05 .{ }^{11}$ Sementara untuk menentukan faktor risiko yang paling bermakna menggunakan analisis multivariat dengan uji regresi logistik, dimana yang akan dilakukan analisis multivariat apabila nilai $\mathrm{p}<0,25$ pada hasil analisisi bivariat. ${ }^{12}$

\section{Hasil}

Hasil penelitian di tiga sekolah dasar Kecamatan Padang Timur, dari 153 total subyek anak usia 7-12 tahun, 6,5\% mengalami kejadian sakit perut berulang.

Hasil analisis yang tertera pada Tabel 1 menunjukkan bahwa paparan kejadian yang dapat menyebabkan stres berasal dari rumah, sekolah, dan tingkat pendidikan orang tua memiliki hubungan dengan kejadian sakit perut berulang pada anak $(\mathrm{p}<0,05)$.

Tabel 1. Faktor yang berhubungan dengan kejadian sakit perut berulang

\begin{tabular}{|c|c|c|c|}
\hline \multirow[b]{2}{*}{ Faktor risiko } & \multicolumn{2}{|c|}{ Sakit perut berulang } & \multirow[b]{2}{*}{$\mathrm{p}$} \\
\hline & $\begin{array}{c}\mathrm{Ya} \\
\mathrm{f}(\%)\end{array}$ & $\begin{array}{l}\text { Tidak } \\
\mathrm{f}(\%)\end{array}$ & \\
\hline Usia (tahun) & & & 0,528 \\
\hline$\leq 10$ & $4(5,1)$ & $74(94,9)$ & \\
\hline$>10$ & $6(8)$ & $69(92)$ & \\
\hline Jenis kelamin & & & 0,742 \\
\hline Laki-laki & $3(5,1)$ & $56(94,9)$ & \\
\hline Perempuan & $7(7,4)$ & $87(92,6)$ & \\
\hline Paparan stres dari rumah & & & 0,009 \\
\hline Ada & $4(26,7)$ & $11(73,3)$ & \\
\hline Tidak & $6(4,3)$ & $132(95,7)$ & \\
\hline Paparan stres dari sekolah & & & 0,041 \\
\hline Ada & $3(23)$ & $10(76,9)$ & \\
\hline Tidak & $7(5)$ & $133(95,7)$ & \\
\hline Pendidikan orang tua & & & 0,022 \\
\hline Rendah & $5(17,2)$ & $24(82,8)$ & \\
\hline Tinggi & $5(4)$ & $119(96)$ & \\
\hline Penghasilan orang tua & & & 0,746 \\
\hline >UMP & $6(7,8)$ & $71(92,2)$ & \\
\hline$<\mathrm{UMP}$ & $4(5,3)$ & $72(94,7)$ & \\
\hline Riwayat keluarga kandung & & & 0,333 \\
\hline Ada & $2(11,1)$ & $16(88,9)$ & \\
\hline Tidak & $8(5,9)$ & $127(94,1)$ & \\
\hline
\end{tabular}

Pada Tabel 2 dipaparkan beberapa kejadian dalam hidup yang dapat menyebabkan stres baik dari rumah maupun dari sekolah. Kejadian dalam hidup dari rumah banyak ditemukan, yaitu perpisahan/perceraian orang tua, pindah rumah, tinggal berpisah dengan orang tua, kelahiran anggota keluarga baru, terdapat anggota keluarga sakit berat, dan salah satu/kedua orang tua meninggal dunia. Sementara di sekolah, kejadian yang didapatkan seperti diganggu/ditindas siswa lain, pindah sekolah, menghadapi ujian, dan mendapatkan hukuman dari guru.

Berdasarkan analisis Tabel 3 ditunjukkan bahwa paparan kejadian dalam hidup yang dapat menyebabkan stres dari rumah merupakan faktor risiko yang paling berhubungan secara signifikan dengan kejadian sakit perut berulang pada anakusia 7-12 tahun di Kecamatan Padang Timur. Anak yang terpapar kejadian dalam hidup yang dapat menyebabkan stres dari rumah 7,8 kali berisiko mengalami sakit perut berulang.

Tabel 2. Paparan kejadian dalam hidup yang dapat menyebabkan stres

\begin{tabular}{lcc}
\hline Bentuk paparan kejadian & $\mathrm{f}$ & $\%$ \\
\hline Kejadian dalam hidup dari rumah & & \\
Perpisahan/perceraian orang tua & 4 & 2,6 \\
Pindah rumah & 4 & 2,6 \\
Tinggal berpisah dengan orang tua & 3 & 2 \\
Kelahiran anggota keluarga baru & 2 & 1,3 \\
$\quad$ Terdapat anggota keluarga yang sakit & 1 & 0,7 \\
berat & & \\
$\quad$ Salah satu/kedua orang tua meninggal & 1 & 0,7 \\
dunia & & \\
Kejadian dalam hidup dari sekolah & & \\
$\quad$ Diganggu/ditindas siswa lain & 4 & 2,6 \\
Pindah sekolah & 3 & 2 \\
$\quad$ Menghadapi ujian sekolah & 2 & 1,3 \\
Mendapat hukuman dari guru & 2 & 1,3 \\
\hline
\end{tabular}

Tabel 3. Faktor risiko kejadian sakit perut berulang pada anak usia 7-12 tahun

\begin{tabular}{lcccc}
\hline \multirow{2}{*}{ Variabel } & \multirow{2}{*}{$\mathrm{p}$} & OR & \multicolumn{2}{c}{$95 \% \mathrm{CI}$} \\
\cline { 4 - 5 } & & & Lower & Upper \\
\hline $\begin{array}{l}\text { Paparan stres dari } \\
\text { rumah }\end{array}$ & 0,006 & 7,804 & 1,785 & 34,130 \\
$\begin{array}{l}\text { Pendidikan orang } \\
\text { tua }\end{array}$ & 0,026 & 0,207 & 0,052 & 0,825 \\
\hline
\end{tabular}




\section{Pembahasan}

Hasil penelitian yang dilakukan di tiga sekolah dasar di Kecamatan Padang Timur pada anak usia 7-12 tahun didapatkan 10 dari 153 anak atau sebanyak 6,5\% mengalami sakit perut berulang. Prevalensi ini lebih rendah dibandingkan dengan hasil yang didapatkan oleh Singh dan Sinha ${ }^{3}$ di India yaitu 10,5\%. Menurut hasil metaanalisis Korterink dkk, ${ }^{8}$ prevalensi sakit perut berulang pada anak bervariasi disetiap negara berkisar antara 1,6\% hingga 41,2\%. Perbedaan ini kemungkinan disebabkan oleh kelompok usia yang diteliti beragam, definisi atau kriteria diagnosis yang berbeda, dan jenis kuesioner yang digunakan.

Hasil penelitian kami mendapatkan adanya hubungan bermakna antara paparan suatu kejadian dalam hidup yang dapat menyebabkan stres baik dari rumah atau sekolah dengan kejadian sakit perut berulang. Hasil penelitian kami sesuai dengan Singh dan Sinha ${ }^{3}$ di India, yang melaporkan adanya hubungan bermakna antara terdapat setidaknya satu atau lebih paparan kejadian dalam hidup yang dapat menyebabkan stres dengan kejadian sakit perut berulang. Beberapa kejadian tersebut seperti ditindas di sekolah dan perpisahan atau perceraian dari orang tua anak.

Adanya paparan suatu kejadian dalam hidup yang dapat menyebabkan stres dapat juga menyebabkan keluhan sakit perut berulang kemungkinan akibat terjadinya mekanisme koping yang buruk terhadap stres. Banyaknya stressor atau pemicu stres menyebabkan terjadinya peningkatan presepsi viseral. Hipersensitifitas viseral dapat terjadi karena peningkatan respon pusat pengendali stres, jalur aurosal, serta peningkatan aktivitas sistem saraf simpatik. ${ }^{8}$

Tingkat pendidikan orang tua juga memiliki hubungan yang bermakna dengan kejadian sakit perut berulang. Orang tua dengan latar belakang pendidikan rendah lebih banyak ditemukan. Hasil penelitian ini sesuai dengan Boey dkk. Berdasarkan laporan Boey $\mathrm{dkk},{ }^{13}$ anak dengan latar belakang pendidikan orang tua rendah memiliki hubungan bermakna dengan kejadian sakit perut berulang. Hubungan tingkat pendidikan orang tua yang rendah berbanding terbalik dengan faktor risiko terjadinya Irritable Bowel Syndrome (IBS). Hal tersebut berkaitan dengan ketersediaan nutrisi dan pelayanan kesehatan, serta kualitas kesehatan yang sehat. ${ }^{14}$
Faktor risiko yang tidak memiliki hubungan bermakna dengan kejadian sakit perut berulang pada penelitian kami adalah usia, jenis kelamin, tingkat penghasilan orang tua, riwayat sakit perut berulang pada keluarga kandung. Keberagaman kelompok usia yang diteliti, definisi atau kriteria diagnosis, dan jenis kuesioner yang digunakan menyebabkan perbedaan hasil penelitian kami dengan penelitian lainnya terhadap faktor yang mempengaruhi kejadian sakit perut berulang. ${ }^{8}$ Menurut Sagawa $\mathrm{dkk}^{15}$ angka kejadian sakit perut berulang meningkat seiring dengan pertambahan usia. Masa remaja awal hingga mencapai usia usia 20 tahun lebih merupakan periode sering terjadinya ansietas dan depresi. ${ }^{16}$ Berdasarkan hasil metaaanalisis Korterink dkk, ${ }^{8}$ kejadian sakit perut berulang dominan terjadi pada anak perempuan, disebabkan peran hormon reproduksi. Hormon tersebut menyebabkan perempuan lebih rentan terhadap stres dan memodulasi proses presepsi nyeri viseral.

Paparan suatu kejadian dalam hidup yang dapat menyababkan stres dari rumah merupakan faktor risiko yang paling berhubungan dengan kejadian sakit perut berulang pada anak usia 7-12 tahun di Kecamatan Padang Timur. Hal tersebut sesuai dengan penelitian Devanarayana $\mathrm{dkk}^{17}$ yang melaporkan bahwa anak dengan paparan terhadap kejadian yang dapat menyebabkan stres memiliki hubungan erat dengan kejadian sakit perut berulang. Tubuh dalam keadaan normal dapat beradaptasi terhadap stressor yang ada dengan mekanisme koping hingga mencapai keadaan homeostasis. Apabila tubuh gagal beradaptasi terhadap stressor yang tinggi dan keadaan tersebut menetap dalam waktu yang lama, menyebabkan aktivasi sumbu hipotalamic-hypopituitari-adrenal (HPA) sebagai respon terhadap keadaan tersebut. Aktivasi sumbu HPA mengakibatkan sekresi corticotropin releasing homrone (CRH) yang dapat menyebabkan terjadinya gejala gangguan sistem pencernaan sesuai lokasi yang terganggu. ${ }^{18}$ Gangguan komunikasi antara sistem saraf pusat dan sistem saraf enterik diperkirakan penyebab terjadinya sakit perut berulang. Anak dengan gangguan pencernaan fungsional cendrung memiliki re-aktivitas usus yang tidak normal terhadap stimulus yang datang, baik stimulus fisiologis (makanan, distensi usus, perubahan hormonal), stimulus stres yang berbahaya bagi tubuh seperti akibat proses inflamasi, dan stimulus psikologis. Hal ini menyebabkan terjadinya hiperalgesia viseral, terjadinya penurunan ambang 
batas nyeri. Hal tersebut menyebabkan nyeri akan lebih mudah terjadi walaupun intensitas rangsangan yang didapat ringan. ${ }^{19}$

\section{Kesimpulan}

Prevalensi anak usia 7-12 tahun di Kecamatan Padang Timur 6,5\% dari 153 anak mengalami sakit perut berulang. Terdapat hubungan bermakna antara paparan kejadian yang dapat menyebabkan stres dari rumah, sekolah, dan tingkat pendidikan orang tua dengan kejadian sakit perut berulang pada anak. Paparan kejadian yang dapat menyebabkan stres dari rumah merupakan faktor risiko sakit perut berulang yang paling berpengaruh pada anak usia 7-12 tahun di Kecamatan Padang Timur.

\section{Daftar pustaka}

1. Boediarso A. Sakit perut pada anak. Dalam: Juffrie M, Soenarto SSY, Oswari H, Arief S, Rosalina I, Mulyani NS, penyunting. Buku ajar gastroenterologi-hepatologi jilid 1. Edisi 3. Jakarta: Badan Penerbit IDAI; 2012.h.149-65.

2. Pace F, Zuin G, Gracomo S, Molteni P, dkk. Family history of irritable bowel syndrome is the major determinant of persistent abdominal complaints in young adults with a history pediatric recurrent abdominal pain. World J Gastroenterol 2006;12:147-51.

3. Singh M, Sinha SK. Etiology of recurrent abdominal pain in children. Int J Med Helath Res 2017;3:3874-77.

4. William L, Wilkins. Chronic abdominal pain in children: a technical report of the American academy of pediatric and North American society for pediatric gastroeneterology, hepatology, and nutrition. J Pediatr Gastroenterol Nutr 2005;40:249-61.

5. Saraswati S, Mohanty S. Recurrent pain abdomen children: an emphasis on base line investigation. Int J Contemporary Med Res 2016;3:2419-22.

6. Motamed F, Mohsenipour R, Seifirad S, dkk. Red flags of organic recurrent abdominal pain in children: study on 100 subject. Iran J Pediatr 2012;22:457-62.

7. Wagley B, Shresta M, Shresta L. Prevalence of helicobacter pylori in children with recurrent abdominal pain. J Institute Medicine 2017;90:353-5.

8. Korterink JJ, Diederen K, Benninga MA, Tabbers MM. Epidemiology of pediatric functional abdominal pain disorders: a metaanalysis. PlosOne 2015;10:1-17.

9. Badan Pusat Statistik Kota Padang. Kecamatan Padang Timur dalam angka. 2018 Des. Diakses 1 Desember 2019. Didapat dari : https://padangkota.bps.go.id.

10. Setiani A. Faktor yang memengaruhi sakit perut berulang pada siswa sekolah menengah pertama di Jakarta Selaatan, tesis. Jakarta: Universitas Indonesia, 2014.

11. Dahlan S. langkah-langkah membuat proposal penelitian dibidang kedokteran kesehatan. Edisi 2. Jakarta: Sagung Seto;2012.

12. Lapau B. Metode penelitian kesehatan. Jakarta: Yayasan Pustaka Obor Indonesia;2012.

13. Boey CCM, Goh KL. Predictors of recurrent abdominal pain among 9 to 15 years old urban school children in Malaysia. Acta Paediatr 2001;90:353-5.

14. Kesuma Y. hubungan masalah perilaku pada remaja dan irritable bowel syndrome. Sari Pediatri 2017;18:492-7.

15. Sagawa T, Okamura S, Kakizaki S, dkk. Functional gastrointestinal disorders in adolescent and quality of school life. J Gastroenterol Hepatol. 2013;28:285-90.

16. Irwin CE, Shafer MA, Ryan SA. Pasien remaja. Dalam: Rudolph AM, penyunting. Buku ajar pediatrik rudolph volume 1. Edisi 20. Jakarta: EGC; 2015.h.42-45.

17. Devanarayana N, Silva DG, Silva HJ. Recurrent abdominal pain syndrome in a cohort of Sri Lankan children and adolescent. J Tropical Paediatr 2008;54:178-83.

18. Saps M, Lorenzo CD. Functional abdominal pain and other functional bowel disorder. Dalam: Guandalini S. Penyunting. Textbook of paediatric gastroenterology and nutrition. United Kingdom: Taylor and Francis; 2004.h.213-29.

19. Alam R, Srakar PC, Saibal AA. Recurrent abdominal pain in children: a review. EMCJ 2016;1:23-28. 